\begin{tabular}{|c|c|}
\hline & $\begin{array}{l}\text { International Journal of Trend in Scientific } \\
\text { Research and Development (IJTSRD) }\end{array}$ \\
\hline $\begin{array}{lll} & \end{array}$ & International Open Access Journal \\
\hline 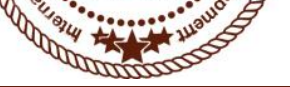 & ISSN No: 2456 - $6470 \mid$ www.ijtsrd.com | Volume - 2 | Issue - 1 \\
\hline
\end{tabular}

\title{
Investigation on Appropriateness of Turbo-matching of B60J68 and A58N70 Turbochargers for a Commercial Vehicle
}

\author{
Badal Dev Roy \\ Research Scholar, Department of Mechanical \\ Engineering, Vels Institute of Science, \\ Technology \& Advanced Studies (VISTAS), \\ Vels University, Chennai, India
}

\author{
Dr.R.Saravanan \\ Research Supervisor, Professor (Mechanical) \& \\ Principal, Ellenki Institute of Engineering and \\ Technology, Hyderabad, TS, India
}

\begin{abstract}
Nowadays turbo-chargers are preferred for commercial vehicle especially to ensure the good operating conditions at higher loads. Turbo-matching is a complex task and carried out by many methods. Recent manufacturing trend added many components in supplier chain. This piece of investigation adopts test based methodologies to perform such matching. The simulation is used to predict the operating conditions at various speeds. The same verified with data-logger method which is like on road test. The routes preferred for evaluating the various routes namely rough road, highway matching performance are: Rough Road, Highway, City Derive, slope up and slope down. The compressor map used for analyse the appropriateness of matching by methods and suggesting the appropriate turbocharger.
\end{abstract}

Keywords: turbo-matching; turbo-charger; chock; surge; simulation; data-logger;

\section{Introduction}

Turbo charger is an accessory in the IC engines to boost pressure, especially at higher loads. Turbo charger also helps to reduce specific fuel consumption (SFC), downsizing the engine, reduce $\mathrm{CO}_{2}$ emission, etc.[1]-[5]. Due to the character of centrifugal compressor, the turbocharged engine yields lesser torque than naturally aspirated engine at lower speeds [6],[7]. Comparatively in diesel engine these problems very worse than petrol engine. Some of the system designs were made to mange this problem. They are: adopting the sequential system [8], incorporate the limiting fuel system, reducing the inertia, improvements on bearing, modification on aerodynamics [9], establishing electrically supported turbocharger [10], the usage of positive displacement charger i.e., secondary charging system and use of either electric compressor or positive displacement charger with turbocharger [10],[11] facilitating the geometrical variation on the compressor and turbine [12], adopting the twin turbo system [13], and dual stage system [14]. It is noticed that the transient condition is always worst with the engine which adopted single stage turbo charger. The variable geometry turbine was introduced for reducing the turbo lag in petrol as well as diesel engines. But the system is not exact match for petrol engines [15]. Even though many research were done on this case still the problem is exist. [12],[15]-[18]. Though the advancements in system design like variable geometry turbine, common rail injection system, and multiple injections, the problem is still persist due to the limiting parameter say supply of air. [19] discussed in detail about the benefits, limitations of turbo charger in single stage, parallel and series arrangements. According to the literature the turbocharger matching is a tedious job and demands enormous skill. The turbo matching can be defined as a task of selection of turbine and compressor for the specific brand of engine to meet its boosting requirements. That is, their combination to be optimized at full load. The trial and error method cannot be adopted in this case because the matching is directly effects as well as affects the engine performance [5],[20],[21]. So it is difficult task and to be worked out preciously. If one chooses the trial and error or non precious method, it will certainly 
lead to lower power output at low speeds for partly loaded engines for the case of two stage turbo charger. It is because of the availability of a very low pressure ratio after every stage than single stage [21]. Some cases the turbocharger characteristics are not readily available, and in some cases, not reliable or influenced by the engine which is to be matched [19]. Nowadays the Simulator is used for matching the turbocharger to the desired engine. The simulator was used to examine the performance at constant speed of $2000 \mathrm{rpm}$ of two stage and single stage turbo chargers, the aim of the study was to optimize the high load limit in the Homogeneous charge compression ignition engine. For increasing the accuracy of matching the test bench method is evolved. Test bench was developed and turbo mapping constructed for various speeds to match the turbocharger for the IC engine by Leufven and Eriksson, but

It is a drawn out process [21]. The on road test type investigation is called Data Logger based Matching method is adopted in this research. [22] discussed the data-logger turbocharger matching method in detail and compared with the result of test best method and simulator based matching method. And proved the data logger method outputs are reliable. By use of the data logger method the performance match can be evaluated with respect to various speeds as well as various road conditions. The core objective of this research is investigating the appropriateness of matching of the turbocharger with B60J68 and A58N70 for the TATA 497 TCIC -BS III Engine by simulator method. The validation of the same by Data Logger based Matching method.

\section{Materials and Methods}

A logical science of combining the quality of turbocharger and engine and which is used to optimize the performance in specific operating range is called as turbo-matching. The Simulation, datalogger method and Test Bed method identified for this evaluation. Apart from the above three this research used the Simulation and data-logger method for evaluating the performance of turbo matching. The trim size is a parameter, which can be obtained from the manufacture data directly or by simple calculation. That is the trim size is a ratio of diameters of the inducer to exducer in percentage. This parameter is closely related to the turbo matching. Various trim sizes are available, but in this study the trim size 68 and 70 are considered for investigation.

\section{A. Simulator Based Matching}

Various kinds of simulation software are being used for turbo matching. In this research the minimatch V10.5 software employed for turbo-matching by simulation. The manufacturer data of the engine and turbocharger are enough to find the matching performance by simulation. The manufacturer data are like turbo configuration, displacement, engine speed, boost pressure, inter cooler pressure drop and effectiveness, turbine and compressor efficiency, turbine expansion ratio etc. The software simulates and gives the particulars of the operating conditions like pressure, mass flow rate, SFC, required power etc. at various speeds. These values are to be marked on the compressor map to know the matching performances. The compressor map is a plot which is used for matching the engine and turbocharger for better compressor efficiency by knowing the position of engine operating points. Based on the position of points and curve join those points the performance of matching will be decided.

\section{B. Data Logger based Matching}

This type of data collection and matching is like on road test of the vehicle. This setup is available in the vehicle with the provision of placing engine with turbocharger and connecting sensors. It is a real time field data gathering instrument called as Data-logger. It is a computer aided digital data recorder which records the operating condition of the engine and turbo during the road test. The inputs are gathering from various parts of engine and turbo charger by sensors. The Graphtec make data logger is employed in this work. It is a computerized monitoring of the various process parameters by means of sensors and sophisticated instruments. The captured data are stored in the system and plot the operating points on the compressor map (plot of pressure ratio versus mass flow rate). The Fig. 1 depicts the setup for the data-logger testing in which the turbocharger is highlighted with red circle.

\section{Decision Making}

The decision making process is based on the position of the operating points on the compressor map. The map has a curved region like an expanded hairpin, in which the left extreme region is called surge region. The operating points fall on the curve or beyond, is said to be occurrence of the surge. That means the mass flow rate limit below the compressor limit. This causes a risk of flow reversal. The right extreme 
region curve is called as Choke region. The points fall on the curve and beyond its right side is denoted as the occurrence of choke. In the choke region the upper mass flow limit above compressor capacity, which causes the quick fall of compressor efficiency, Chances for compressor end oil leakage and insufficient air supply. The all operating points fall in between those extreme regions i.e., the heart region holds good. It must be ensured at all levels of operation of the engine holds good with the turbocharger. The manufacturer of Turbocharger provides the compressor map for each turbo charger based on its specifications.

\section{Engine Specifications}

Table I: Specification of Engine

\begin{tabular}{|l|l|}
\hline Description & Specifications \\
\hline $\begin{array}{l}\text { Fuel Injection } \\
\text { Pump }\end{array}$ & Electronic rotary type \\
\hline Engine Rating & $92 \mathrm{KW} \mathrm{(125} \mathrm{PS)@2400} \mathrm{rpm}$ \\
\hline Torque & $400 \mathrm{Nm} @ 1300-1500 \mathrm{rpm}$ \\
\hline $\begin{array}{l}\text { No. of } \\
\text { Cylinders }\end{array}$ & 4 Cylinders in-line water cooled \\
\hline Engine type & DI Diesel Engine \\
\hline $\begin{array}{l}\text { Engine Bore } \\
\text { Engine Stroke }\end{array}$ & $97 \mathrm{~mm} / 128 \mathrm{~mm}$. \\
\hline Engine speed & $\begin{array}{l}2400 \text { rpm (Max power), 1400 } \\
\text { rpm (Max Torque) }\end{array}$ \\
\hline
\end{tabular}

The TATA 497 TCIC -BS III engine is a common rail type diesel engine. It is commonly used for medium type commercial vehicle like Tata Ultra 912 \& Tata Ultra 812 trucks. The engine develops 123.29 BHP at $2,400 \mathrm{rpm}$ and also develops the peak torque of 400 $\mathrm{Nm}$ between 1,300 and $1,800 \mathrm{rpm}$. The other specifications can be found in Table 1 .

\section{E. Turbochargers Specifications}

The TATA Short Haulage Truck, turbochargers of B60J68 and A58N70 are considered to examine the performance of matching for TATA 497 TCIC -BS III engine. For example, if specification A58N70 means in which the A58 is the design code and N70 is the
Trim Size of the turbocharger in percentage. The other specifications furnished in Table 2.

Table II: Specification of Turbo Chargers

\begin{tabular}{|l|l|l|}
\hline Description & B60J68 & A58N70 \\
\hline $\begin{array}{l}\text { Turbo maximum } \\
\text { Speed }\end{array}$ & 200000 rpm \\
\hline Turbo Make & \multicolumn{2}{|l|}{ HOLSET } \\
\hline Turbo Type & $\begin{array}{l}\text { WGT-IC (Waste gated Type } \\
\text { with Intercooler) }\end{array}$ \\
\hline Trim Size (\%) & 68 & 70 \\
\hline Inducer Diameter & $46.9 \mathrm{~mm}$ & $48.6 \mathrm{~mm}$ \\
\hline Exducer Diameter & $\begin{array}{l}68.9 \\
\mathrm{~mm}\end{array}$ & $69.4 \mathrm{~mm}$ \\
\hline
\end{tabular}

\section{Experimental Observation}

The simulation and data-logger method is adopted to match the Turbo Chargers B60J68 and A58N70 for TATA 497 TCIC -BS III engine. The matching performance is obtained by simulation by using the data from the manufacturer catalogue. The desired combination is simulated at various speeds (1000, 1400,1800 and $2400 \mathrm{rpm}$ ) to obtain the predicted operating conditions for this combination. The Pressure ratio and mass flow rates are important parameters to know the turbo matching performance. The simulated observations presented in the Table 3 for B60J68 and A58N70 Turbo matching. In datalogger method the turbocharger is connected to the TATA 497 TCIC -BS III Engine of TATA 1109 TRUCK with sensors. The vehicle loaded to rated capacity 7.4 tonnes of net weight. The grass weight of vehicle is 11 tonnes. The experimental setup for Data logger type matching is shown in 
International Journal of Trend in Scientific Research and Development (IJTSRD) ISSN: 2456-6470

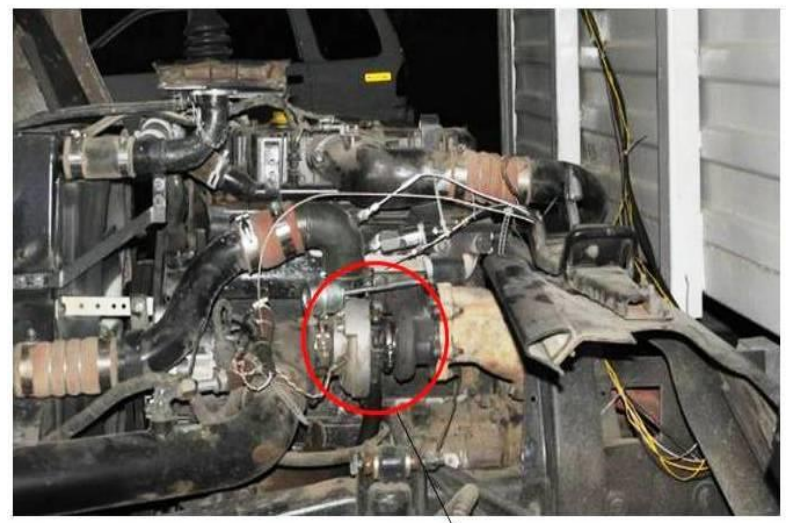

Fig. I Data-Logger method Experimental set up

Table III Simulated observations

\begin{tabular}{|l|l|l|l|l|l|}
\hline $\begin{array}{l}\text { S.N } \\
0\end{array}$ & $\begin{array}{l}\text { Engin } \\
\text { e } \\
\text { Speed } \\
\text { (rpm) }\end{array}$ & \multicolumn{2}{|l|}{$\begin{array}{l}\text { Mass Flow Rate } \\
\text { Kg/sec.squrt }\end{array}$} & \multicolumn{2}{|l|}{$\begin{array}{l}\text { Pressure Ratio } \\
\text { K/Ma) }\end{array}$} \\
\cline { 3 - 6 } & $\begin{array}{l}\text { B60J6 } \\
8\end{array}$ & $\begin{array}{l}\text { A58N7 } \\
0\end{array}$ & $\begin{array}{l}\text { B60J6 } \\
8\end{array}$ & $\begin{array}{l}\text { A58N7 } \\
0\end{array}$ \\
\hline 1 & 1000 & 11.449 & 9.534 & 1.856 & 1.856 \\
\hline 2 & 1400 & 22.56 & 20.186 & 3.051 & 3.042 \\
\hline 3 & 1800 & 29.451 & 27.958 & 3.556 & 3.548 \\
\hline 4 & 2400 & 36.872 & 35.488 & 3.817 & 3.764 \\
\hline
\end{tabular}

Table IV Data-logger - Rough Road observations

\begin{tabular}{|l|l|l|l|l|l|}
\hline S. & $\begin{array}{l}\text { Engine } \\
\text { Speed } \\
\text { No }\end{array}$ & \multicolumn{2}{|l|}{$\begin{array}{l}\text { Mass Flow Rate } \\
\text { (Kg/sec.squt } \\
\text { K/Mpa) }\end{array}$} & \multicolumn{2}{l|}{ Pressure Ratio } \\
\hline & B60J68 & A58N70 & B60J68 & A58N70 \\
\hline 1 & 1000 & 7.37 & 8.43 & 1.35 & 1.29 \\
\hline 2 & 1400 & 15.41 & 16.27 & 1.95 & 1.9 \\
\hline 3 & 1800 & 21.73 & 23.87 & 2.33 & 2.29 \\
\hline 4 & 2400 & 27.43 & 28.49 & 2.55 & 2.51 \\
\hline
\end{tabular}

Table V observations

\begin{tabular}{|l|l|l|l|l|l|}
\hline S. & $\begin{array}{l}\text { Engine } \\
\text { Speed } \\
\text { No }\end{array}$ & \multicolumn{2}{|l|}{$\begin{array}{l}\text { Mass Flow Rate } \\
\text { (Kg/sec.squr } \\
\text { K/Mpa) }\end{array}$} & \multicolumn{2}{l|}{ Pressure Ratio } \\
\cline { 3 - 6 } & & B60J68 & A58N70 & B60J68 & A58N70 \\
\hline 1 & 1000 & 8.12 & 8.52 & 1.35 & 1.31 \\
\hline 2 & 1400 & 15.92 & 16.39 & 1.95 & 1.87 \\
\hline 3 & 1800 & 21.87 & 23.94 & 2.33 & 2.3 \\
\hline 4 & 2400 & 27.87 & 28.91 & 2.56 & 2.51 \\
\hline
\end{tabular}

Table VI Data-logger - City Drive observations

\begin{tabular}{|l|l|l|l|l|l|}
\hline S. & $\begin{array}{l}\text { Engine } \\
\text { Npeed } \\
\text { No }\end{array}$ & $\begin{array}{l}\text { Mass Flow Rate } \\
\text { (Kg/sec.squrt } \\
\text { K/Mpa) }\end{array}$ & \multicolumn{2}{l|}{ Pressure Ratio } \\
\cline { 3 - 6 } & & B60J68 & A58N70 & B60J68 & A58N70 \\
\hline 1 & 1000 & 7.41 & 8.49 & 1.36 & 1.32 \\
\hline 2 & 1400 & 15.52 & 16.31 & 1.95 & 1.95 \\
\hline 3 & 1800 & 21.68 & 23.78 & 2.35 & 2.33 \\
\hline 4 & 2400 & 27.39 & 28.37 & 2.59 & 2.56 \\
\hline
\end{tabular}

Table VII Data-logger-slope Up observations

\begin{tabular}{|l|l|l|l|l|l|}
\hline \multirow{2}{*}{\begin{tabular}{l} 
No \\
\multirow{2}{*}{}
\end{tabular}} & $\begin{array}{l}\text { Engine } \\
\text { Speed } \\
\text { (rpm) }\end{array}$ & \multicolumn{2}{|l|}{$\begin{array}{l}\text { Mass Flow Rate } \\
\text { Kg/sec.squt }\end{array}$} & \multicolumn{2}{l|}{ Pressure Ratio } \\
\cline { 3 - 6 } & B60J68 & A58N70 & B60J68 & A58N70 \\
\hline 1 & 1000 & 8.02 & 8.58 & 1.38 & 1.31 \\
\hline 2 & 1400 & 15.81 & 16.34 & 2.00 & 2.00 \\
\hline 3 & 1800 & 21.94 & 23.98 & 2.39 & 2.37 \\
\hline 4 & 2400 & 27.97 & 28.98 & 2.62 & 2.58 \\
\hline
\end{tabular}


International Journal of Trend in Scientific Research and Development (IJTSRD) ISSN: 2456-6470

Table VIII Data-logger - Slope Down observations

\begin{tabular}{|l|l|l|l|l|l|}
\hline $\begin{array}{l}\text { S. } \\
\text { No }\end{array}$ & $\begin{array}{l}\text { Engine } \\
\text { Speed } \\
\text { (rpm) }\end{array}$ & \multicolumn{2}{|l|}{$\begin{array}{l}\text { Mass Flow Rate } \\
\text { K/Mec.squrt }\end{array}$} & \multicolumn{2}{l|}{ Pressure Ratio } \\
\cline { 3 - 6 } & B60J68 & A58N70 & B60J68 & A58N70 \\
\hline 1 & 1000 & 7.97 & 8.47 & 1.35 & 1.30 \\
\hline 2 & 1400 & 15.79 & 16.32 & 1.95 & 1.95 \\
\hline 3 & 1800 & 21.76 & 23.89 & 2.33 & 2.31 \\
\hline 4 & 2400 & 27.41 & 28.42 & 2.60 & 2.50 \\
\hline
\end{tabular}

Fig 1. The operating conditions collected while driving at a specific speed in the selected route. For the same set of engine speeds the operating conditions were observed while vehicle driving in the routes like Rough Road, Highway, City Drive, Slope up and Slope down. The observations were recorded in the data-logger automatically through sensors. Those data logger observations were tabulated road condition wise from Table 4 to Table 8.

\section{Results and Discussions}

The operating conditions obtained for both case of turbo-chargers with engine for both simulator and data-logger method with rough road route, highway route, city drive, slope-up and slope-down route were obtained. These operating conditions were marked on the respective compressor map. The Fig.2 and Fig. 3 are for turbo-matching B60J68 turbocharger and A58N70 Turbochargers for TATA 497 TCIC -BS III Engine respectively for both methods especially at Rough Road route condition. Similarly Fig.4 and Fig.5 for Highway route, Fig.6 and Fig.7 for City Drive route, Fig.8 and Fig.9 for Slope up and Fig.10 and Fig.11 for Slope down. It was observed from the compressor maps (Fig.2 to Fig.11) that the both the turbo chargers performing well all speeds at all preferred routes. The simulated values are much higher than the data-logger values. Especially at higher speed the turbo-match is very perfect. In particularly the B60J68 turbocharger's turbo-match, operating condition lower speed is nearby surge line. The turbomatch of A58N70 turbocharger is found safe at all speeds as well as all routes preferred for evaluation. Hence the A58N70 turbocharger can be best match than B60J68 turbocharger.

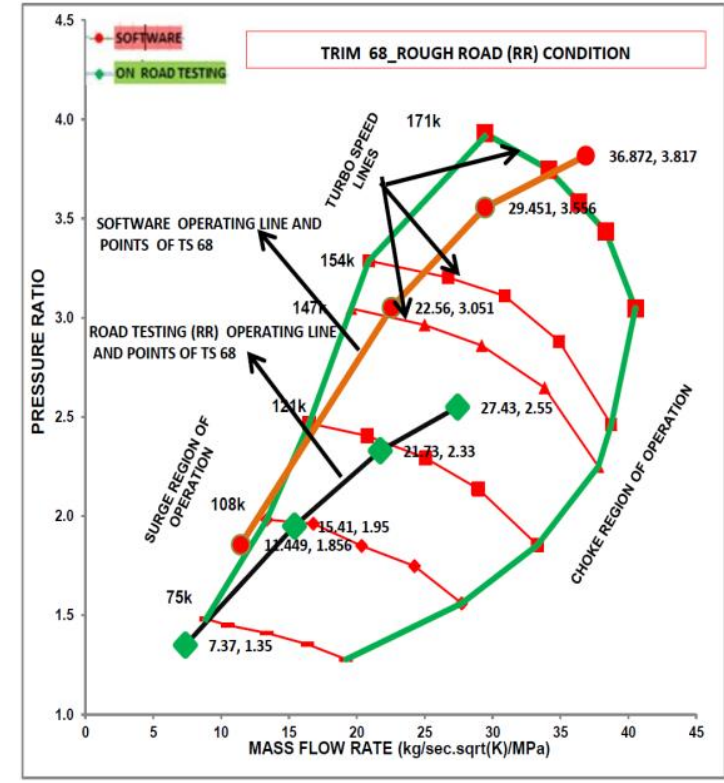

Fig. II B60J68 Turbo-match-Rough Road

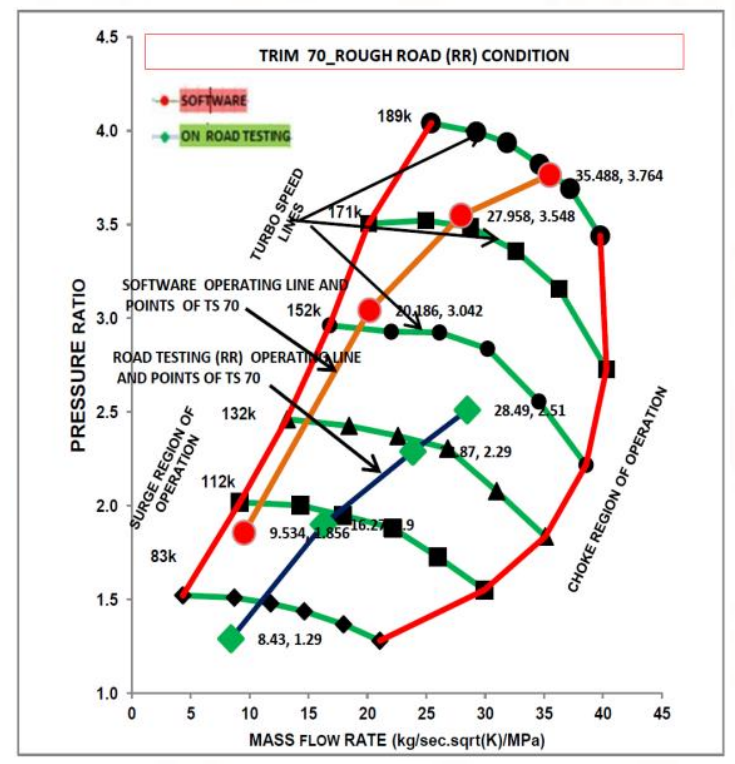

Fig. III A58N70 Turbo-match-Rough Road 
International Journal of Trend in Scientific Research and Development (IJTSRD) ISSN: 2456-6470

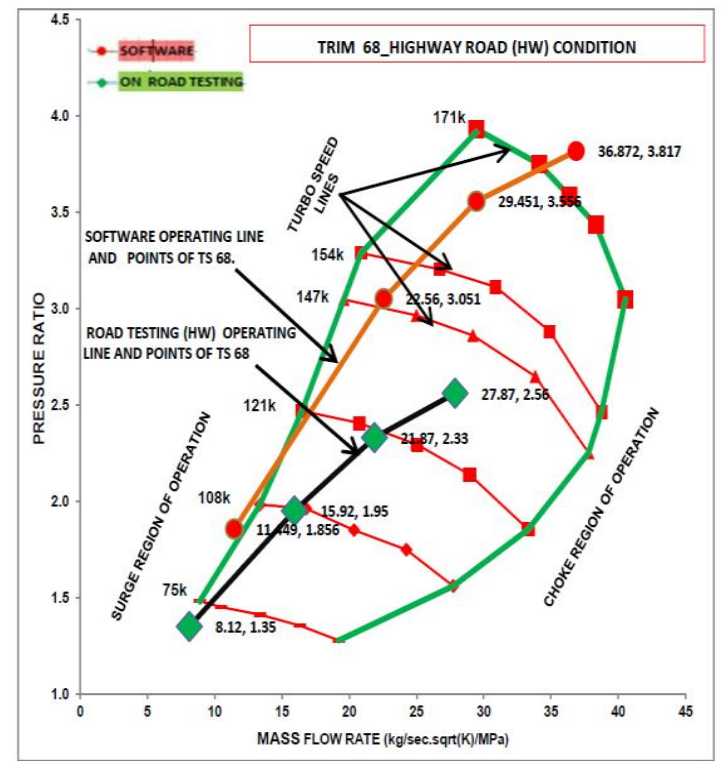

Fig. IV B60J68 Turbo-match - Highway

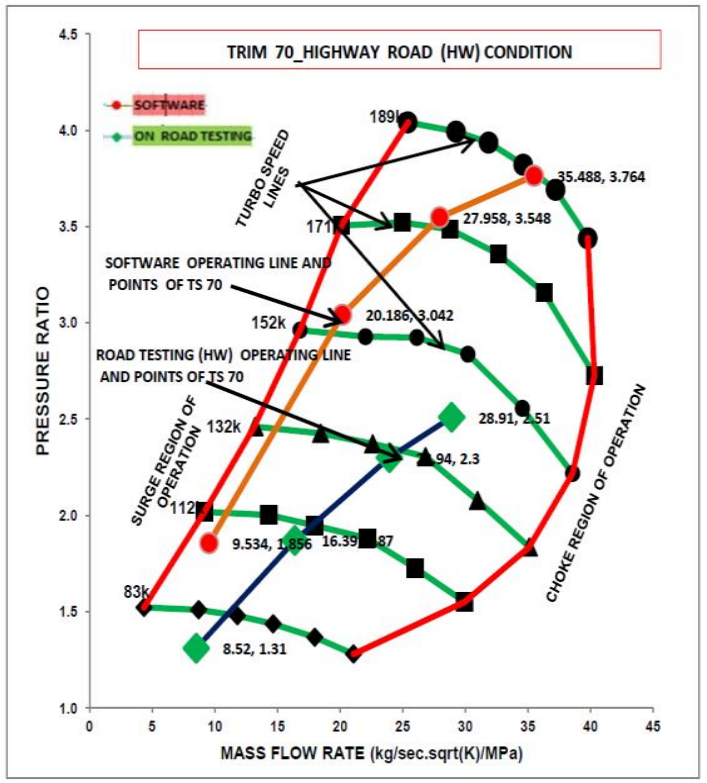

Fig. V A58N70 Turbo-match- Highway

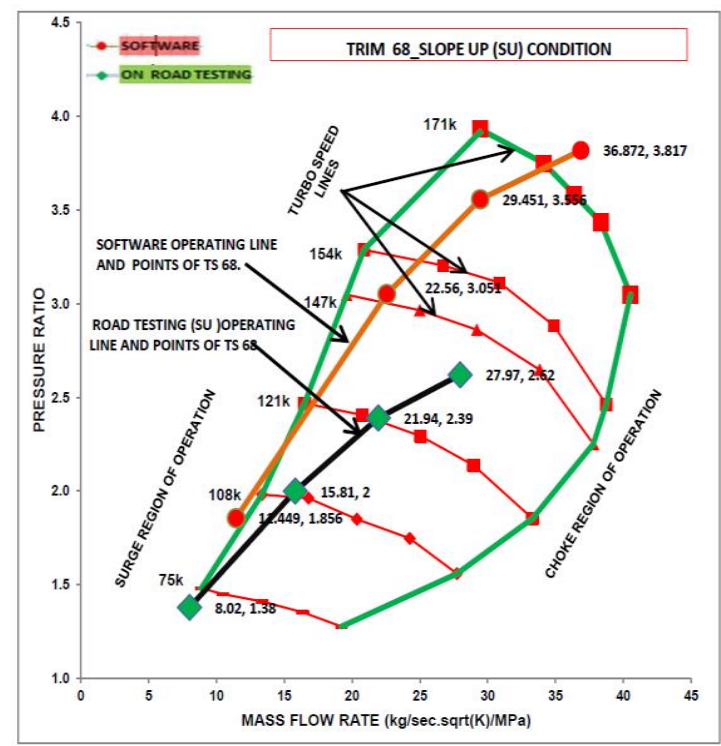

Fig. VI B60J68 Turbo-match- slope-up

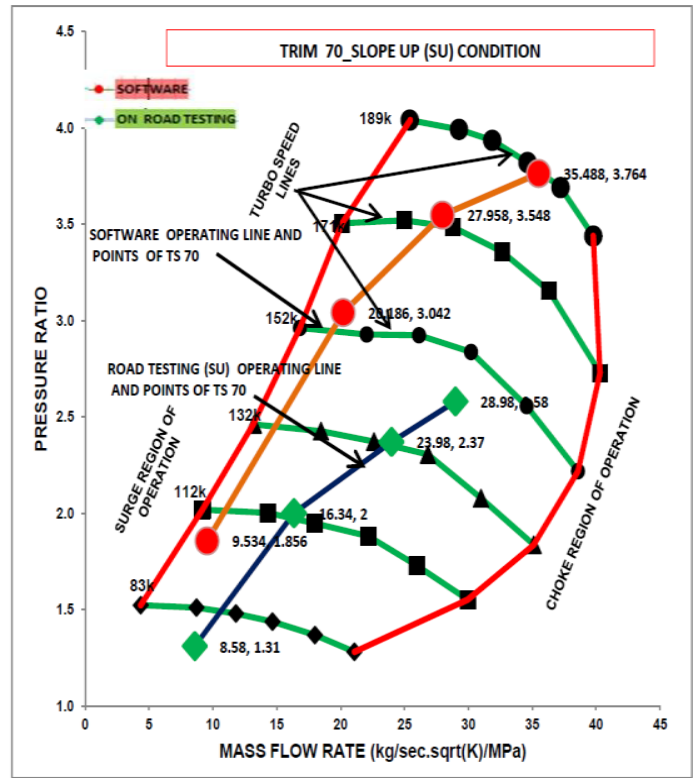

Fig. VIII A58N70 Turbo-match - Slope-up

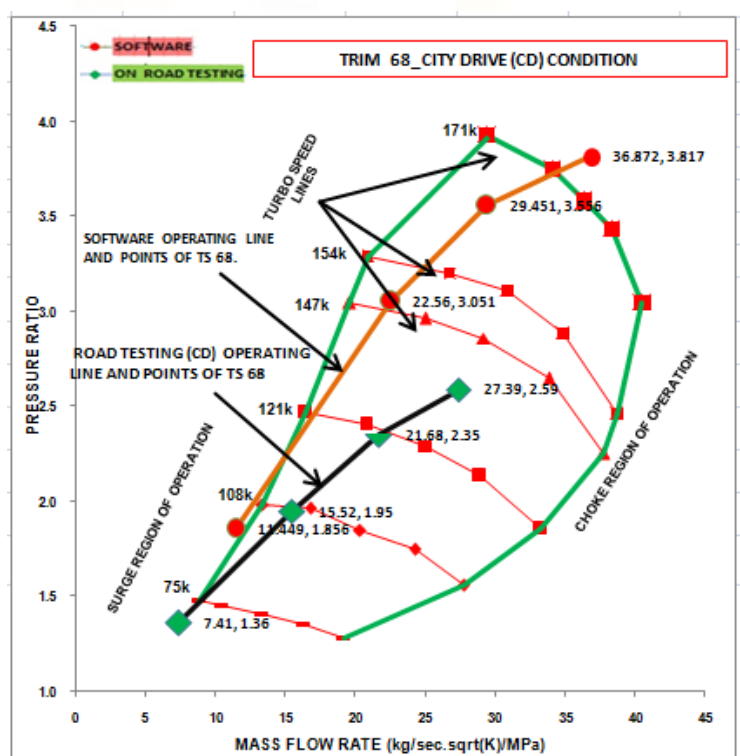

Fig. VIII B60J68 Turbo-match- City Drive

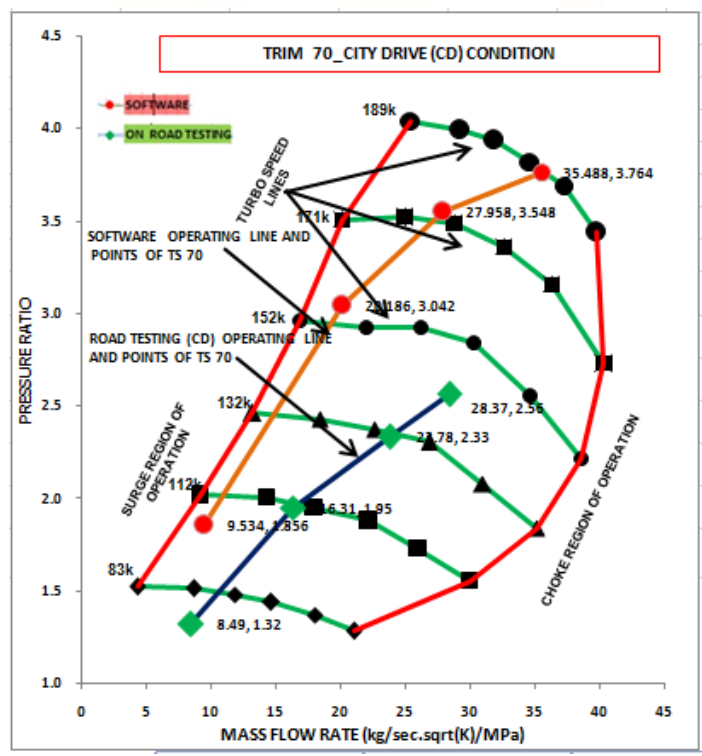

Fig. IX A58N70 Turbo-match- City Drive 


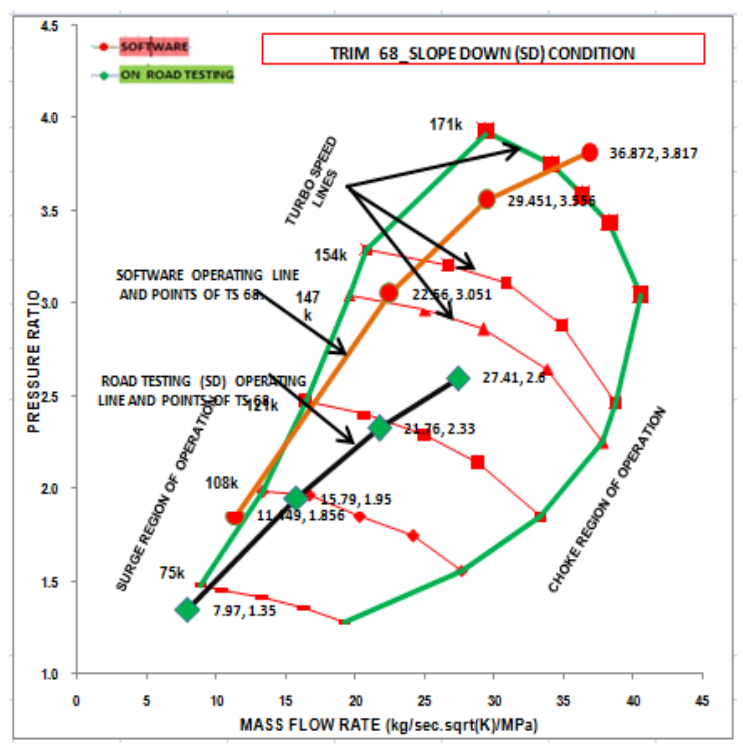

Fig. X B60J68 Turbo-match- Slope Down

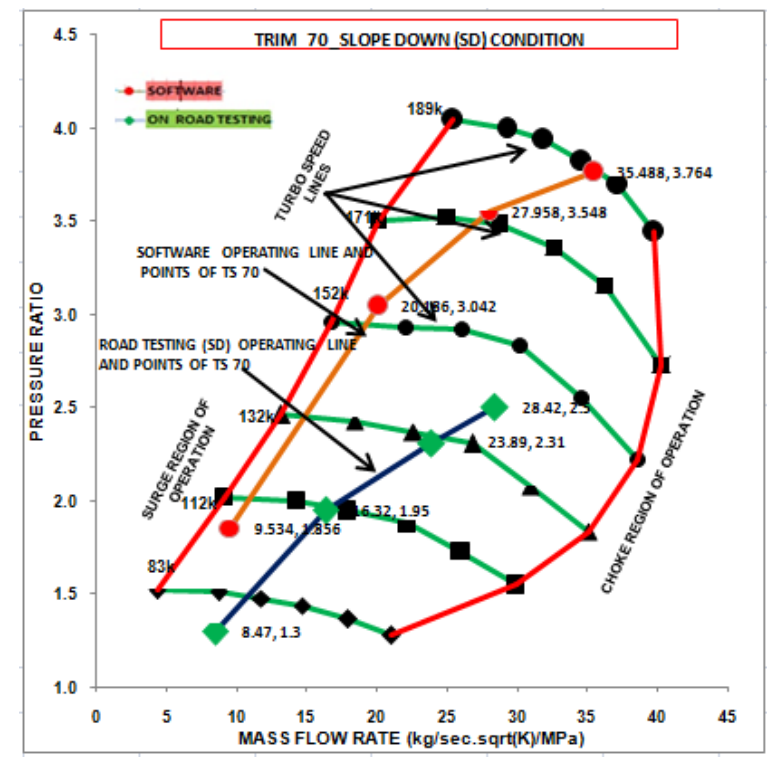

Fig. XI A58N70 Turbo-match- Slope Down

\section{CONCLUSION}

The turbo-matching of B60J68 turbocharger and A58N70 turbocharger for TATA 497 TCIC -BS III engine is considered. The turbo-charger B60J68 performs well at all operating fields but its lower speed's operating conditions found nearby the surge region. Because, the operations of vehicle at lower speed, the surge occurs at flow. The same operating performance was observed in simulated solution as well as data-logger method with irrespective of routes. The turbocharger A58N70 operating performance shows that the turbo-match is good at all speeds. As the A58N70 turbo-match satisfy the operating performance on both methods. A58N70 turbo-charger is found match TATA 497 TCIC -BS III engine. The data-logger method adapted in this research may feel as expensive but it is one time job for finding the best turbo-match for an engine category.

\section{ACKNOWLEDGEMENTS}

The authors acknowledge $\mathrm{M} / \mathrm{s}$ the Cummins Turbo Technology and ARAI, Pune for their support and contribution for this research work. The authors also acknowledge to the Dr.M.Chandrasekaran, Joint Supervisor, Professor \& Director / Mechanical Engineering, Vels University, Dr.C.Dhanasekaran, Professor \& Head / Mechanical Engineering, Coordinator for School of Engineering, Vels University. Chennai., Dr.V.Muthukumar, Professor, DC Member and Dr.S.Santhanam, Professor, DC Member for their valuable suggestion to carried out this piece of research.

\section{REFERENCES}

1) G.Cantore, E.Mattarelli, and S.Fontanesi, "A New Concept of Supercharging Applied to High Speed DI Diesel Engines," SAE Technical Paper 2001-01-2485, 2001, pp.1-17, doi:10.4271/2001-012485, 2001.

2) L.Guzzella, U.Wenger, and R.Martin, "ICEngine Downsizing and Pressure-Wave Supercharging for Fuel Economy," SAE Technical Paper 2000-01-1019, 2000, pp.1-7, doi: 10.4271/2000-01-1019, 2000.

3) B. Lecointe and G.Monnier, "Downsizing a Gasoline Engine Using Turbocharging with Direct Injection," SAE Technical Paper 2003-01-0542, 2003, pp.1-12, doi: 10.4271/2003-01-0542, 2003.

4) S.Saulnier and S.Guilain, "Computational Study of Diesel Engine Downsizing Using TwoStageTurbocharging," SAE Technical Paper 2004-010929, 2004, pp.1-9, doi: 10.4271/2004-01-0929, 2004.

5) T.Lake, J.Stokes, R.Murphy and R.Osborne, "Turbocharging Concepts for Downsized DI Gasoline Engines," SAE Technical Paper 2004-01-0036, 2004, pp.1-13, doi: 10.4271/2004-01-0036, 2004.

6) W.Attard, H.Watson, S.Konidaris and M.Khan, "Comparing the Performance and Limitations of a Downsized Formula SAE Engine in Normally Aspirated, Supercharged and Turbocharged Modes," SAE Technical Paper 2006-32-0072, 2006, pp.1-22, doi: 10.4271/2006-32-0072, 2006. 
7) A.Lefebvre and S.Guilain, "Modelling and Measurement of the Transient Response of a Turbocharged SI Engine," SAE Technical Paper 2005-01-0691, 2005, doi: 10.4271/2005-01-0691, 2005, pp.1-15.

8) S.Tashima, H.Okimoto, Y.Fujimoto, and M.Nakao, "Sequential Twin Turbocharged Rotary Engine of the Latest RX-7," SAE Technical Paper 941030, 1994, doi: 10.4271/941030, 1994, pp.1-10.

9) T.Watanabe, T.Koike, H.Furukawa, N.Ikeya, "Development of Turbocharger for Improving Passenger Car Acceleration," SAE Technical Paper 960018, 1996, doi: 10.4271/960018, 1996, pp.1-9.

10) T.Kattwinkel, R.Weiss and J.Boeschlin, "Mechatronic Solution for Electronic Turbocharger," SAE Technical Paper 2003-01-0712, 2003, pp.1-8, doi: 10.4271/2003-01-0712, 2003.

11) N.Ueda, N.Matsuda, M.Kamata, H.Sakai, "Proposal of New Supercharging System for Heavy Duty Vehicular Diesel and Simulation Results of Transient Characteristics," SAE Technical Paper 2001-01-0277, 2001, pp.1-9, doi: 10.4271/2001-010277, 2001.

12) J.Kawaguchi, K.Adachi, S.Kono and T.Kawakami, "Development of VFT (Variable Flow Turbocharger)," SAE Technical Paper 1999-01-1242, 1999, doi: 10.4271/1999-01-1242, 1999, pp.1-8.

13) C.Cantemir, "Twin Turbo Strategy Operation," SAE Technical Paper 2001-01-0666, 2001, doi: 10.4271/2001-01-0666, 2001, pp.1-11.

14) C.Choi, S.Kwon and S.Cho, "Development of Fuel Consumption of Passenger Diesel Engine with 2 Stage Turbocharger," SAE Technical Paper 2006-010021, 2006, doi: 10.4271/2006-01-0021, 2006, pp.1-9.

15) J.Andersen, E.Karlsson and A.Gawell, "Variable Turbine Geometry on SI Engines," SAE Technical Paper 2006-01-0020, 2006, doi: 10.4271/2006-01-0020, 2006, pp.1-15.

16) Z.Filipi, Y.Wang and D.Assanis, "Effect of Variable Geometry Turbine (VGT) on Diesel Engine and Vehicle System Transient Response," SAE Technical Paper 2001-01-1247, 2001, pp.1-21, doi: 10.4271/2001-01-1247, 2001.

17) C.Brace, A.Cox, J.Hawley and N.Vaughan, et al., "Transient Investigation of Two Variable
Geometry Turbochargers for Passenger Vehicle Diesel Engines," SAE Technical Paper 1999-01-1241, 1999, doi: 10.4271/1999-01-1241, 1999, pp.1-17.

18) S.Arnold, M.Groskreutz, S.Shahed and K.Slupski, "Advanced Variable Geometry Turbocharger for Diesel Engine Applications," SAE Technical Paper 2002-01-0161, 2002, pp. 1-12, doi: 10.4271/2002-01-0161, 2002.

19) Qingning Zhang, Andrew Pennycott, Chris J Brace, 'A review of parallel and series turbocharging for the diesel engine' Proceedings of the Institution of Mechanical Engineers, Part D: Journal of Automobile Engineering.Volume: 227 issue: 12, Sep. 2013, pp. 1723-1733.

https://doi.org/10.1177/0954407013492108.

20) F.Millo, F.Mallamo and G.Mego,, "The Potential of Dual Stage Turbocharging and Miller Cycle for HD Diesel Engines," SAE Technical Paper 2005-01-0221, 2005, pp. 1-12, doi:10.4271/2005-010221, 2005.

21) N.Watson and M.S.Janota, Wiley-Interscience Ed. "Turbocharging the internal combustion engine,", Diesel motor - 1982, 608 pages. https://doi.org/10.1007/978-1-349-04024-7

22) Badal Dev Roy, R.Saravanan, R.Pugazhenthi and M.Chandrasekaran, "Experimental Investigation of Turbocharger Mapped by Data-logger in I.C. Engine" ARPN Journal of Engineering and Applied Sciences, 11 (7), April 2016, pp. 4587 4595. 